Islamic Environmental Systems Engineering 
Macmillan International College Editions (MICE) are authoritative paperback books covering the history and cultures of the developing world, and its scientific, technical, social and economic development. The MICE programme contains many distinguished series in a wide range of disciplines, some titles being regionally biased, others more international. Library editions will usually be published simultaneously with the paperback editions.

Other titles of interest

H. S. Murison and J. P. Lee Housing in Third World Countriesperspectives on policy and practice

H. Enayat Modern Islamic Political Thought

S. Aziz Rural Development-learning from China

P. K. Hitti History of the Arabs 


\section{Islamic Environmental Systems Engineering}

A systems study of environmental engineering, and the law, politics, education, economics and sociology of science and culture of Islam

S. Waqar Ahmed Husaini 
(C) S. Waqar Ahmed Husaini 1980

Softcover reprint of the hardcover 1st edition 1980 978-0-333-26138-5

All rights reserved. No part of this publication may be reproduced or transmitted, in any form or by any means, without permission.

First published 1980 by

THE MACMILLAN PRESS LTD

London and Basingstoke

Associated companies throughout the world

Filmset by Vantage Photosetting Co. Ltd.

Southampton and London

ISBN 978-0-333-26139-2

ISBN 978-1-349-16441-7 (eBook)

DOI 10.1007/978-1-349-16441-7

This book is sold subject to the standard conditions of the Net Book Agreement.

The paperback edition of this book is sold subject to the condition that it shall not, by way of trade or otherwise, be lent, re-sold, hired out, or otherwise circulated without the publisher's prior consent in any form of binding other than that in which it is published and without a similar condition including this condition being imposed on the subsequent purchaser. 
To Stanford University, California and

the best in the West 


\section{Contents}

Acknowledgements xiii

1 The Quranic Spirit 1

Islam 1

Revelation and reason in the Quran $\quad 2$

The scope and function of scriptural revelation 3

Succession of prophets, and culmination of scriptural revelation 3

Reason, empiricism, traditionalism, authority and freedom 5

$\begin{array}{ll}\text { Critique of pure reason } & 7\end{array}$

$\begin{array}{ll}\text { Reason and scriptural revelation are complementary } & 7\end{array}$

Axiological systematisation as methodology for apprehending the
Quran

Quranic personal and social ethics: concept of man, nature, and $\begin{array}{ll}\text { altruistic humanism } & 9\end{array}$

2 Islamic jurisprudence: revealed law (shari'a) and derived or $\begin{array}{lr}\text { substantive law (fiqh) } & 16\end{array}$

$\begin{array}{ll}\text { Introduction } & 16\end{array}$

History of Islamic law and civilisation $\quad 16$

$\begin{array}{ll}\text { Medieval Islamic law } & 16\end{array}$

Decline of the medieval islamic civilisation: causes and consequences $\quad 18$

$\begin{array}{ll}\text { Revival of Islamic law and culture } & 22\end{array}$

Methodology of Islamic jurisprudence $\quad 24$

$\begin{array}{ll}\text { Sources of shari' } a & 24\end{array}$

$\begin{array}{ll}\text { The Quran: primary source } & 24\end{array}$

The Sunnah or Hadith (traditions or sayings of the Prophet

Fundamental principles of shari' $a$ : primary sources of figh 25

$\begin{array}{ll}\text { Qiyās (analogical reasoning) } & 26\end{array}$

$\begin{array}{ll}\text { Ijmä'(consensus) } & 27\end{array}$

Fundamental principles of shari' $a$ : secondary sources of fiqh 27

$\begin{array}{ll}\text { Pre-Quranic revelations } & 28\end{array}$

Istihsān (preference for the better) 29

Istișlāhor al-Maṣlaha (public interest) $\quad 29$

'Urf, '‘்dah, $t$ 'ämul(custom and usage) 30

Foreign sources of figh $\quad 30$

Leniency (taysīr) under compulsion or constraint (iḍtirār), or in
dire necessity (darūra)

The spirit and scope of shari' $a$ and fiqh 31

Implications of the sources of $\operatorname{shari}^{-} a$ and fiqh for development strategies: imitative-innovative assimilation 
3 Islamic philosophy of knowledge and education: classification and outline of environmental engineering systems planning education

Introduction

Islamic philosophy of knowledge and education according to AlGhazali (AH 450-505/AD 1058-1111) 35

Classification of knowledge $\quad 35$

Classification of knowledge by level of obligatoriness $\quad 35$

$\begin{array}{ll}\text { Classification of knowledge by source } & 37\end{array}$

$\begin{array}{ll}\text { Classification of knowledge by social function } & 37\end{array}$

$\begin{array}{ll}\text { Blameworthy and praiseworthy sciences: criteria } & 37\end{array}$

Sciences blameworthy for sociological reasons 38

Sciences blameworthy for shari' $a$ reasons: Al-Ghazali's critique and Ibn Rushd's defence of 'philosophers' $\quad 39$

Praiseworthy 'philosophical' sciences $\quad 41$

Educational and research planning $\quad 41$

Discussion $\quad 42$

Islamic philosophy of knowledge according to Ibn Khaldun

(AH 732-808/AD 1332-1406) 44

Classification of knowledge $\quad 45$

Shari' $a$-based (shar'iyya), or transmitted (naqliyya), or positive (wad'iyya) sciences

The 'philosophical' (falsafiyya), or rational/intellectual ( 'aqliyya) or 'natural' ( $t a b \bar{i}$ 'iyya) sciences

The shar'iyya and 'philosophical' sciences: disentangling their confused inter-relations

Discussion

An Islamic classification of disciplines comprising environmental engineering systems planning

Shari' $a$-susceptive realm of environmental engineering systems planning

Universal rational realm of environmental engineering systems planning

Developing Islamic environmental engineering systems planning through imitative-innovative assimilation

Imitative-innovative assimilation in the $\operatorname{shari}^{-} a$-susceptive realm of environmental engineering systems planning

Imitative-innovative assimilation in the universal rational realm of environmental engineering systems planning

Islamic engineering education: the teaching of humanistic-social sciences in technical education to Muslim and non-Muslim students in the Islamic setting

Humanistic-social sciences stem of undergraduate engineering education in non-Islamic states

Humanistic-social sciences stem of Islamic engineering education: structure and subject matter

Islamic philosophy and sociology of science, and the history of medieval science and technology

Islamic ethics: inculcation of creative, altruistic professionalism

Transfer of science and technology, and transmission of shari' $a$ susceptive sciences

Discussion 
4 Implications of Islamic jurisprudence for environmental engineering systems planning: the case of water law

Introduction

Implications of the sources of $\operatorname{shari'}^{-} a$

The Quran

The 'legal, binding Sunnah'

The Majallah: some possible shari' $a$ legal maxims pertinent to environmental engineering systems planning

Implications of fundamental principles of $\operatorname{shari}^{-6} a$ : the primary sources of

Qiyās fiqh

Ijmā

Implications of fundamental principles of $\operatorname{sh}^{-1}{ }^{\prime} a$ : the secondary sources of fiqh

Istiṣlāḥ or al-Maṣlaḥa

Istihsān

'Urf: Muslim customary law or traditional fiqh

Foreign sources (non-Muslim)

86

Taysīr under Idṭtirār or darūra

Tadrīj

Transition from Islamic customary (traditional) law to modern $i j m \bar{a}^{\star}$ legislation

\section{Islamic state and comparative politics: implications for} environmental engineering systems planning 92

$\begin{array}{ll}\text { Introduction } & 92\end{array}$

Principles of the Islamic ( $\left.\operatorname{shari}^{-} a\right)$ state $\quad 93$

Sovereignty $\quad 93$

Shūrā and Ijmä ‘

Rights of citizens, Muslim and non-Muslim $\quad 94$

Rights of the Islamic state $\quad 94$

Special rights and limitations of non-Muslim citizens $\quad 94$

Ikhtiläf, and the decisive consensus $\quad 95$

Subsidiary principles on division of governmental functions: relation between legislature and executive

Interdependence of legislative and executive functions 95

$\begin{array}{lr}\text { Executive powers } & 95\end{array}$

Integration of legislative and executive functions $\quad 95$

Judicial arbitration between legislature and executive 95

A model Islamic state: the Rightly Guided Caliphate (АН 11-41/ AD 632-661)

$\begin{array}{cc}\text { Typology of states and political cultures } & 96 \\ \text { Review of Islamic political thought } & 96\end{array}$

Ibn Khaldun's Islamic typology of states and political cultures 97

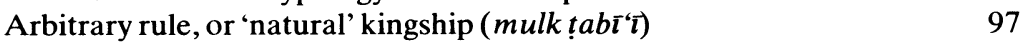

Rational regimes (siyāsāt 'aqliyya) 97

The rational regime whose primary end is this-worldly public interest ( mașālih 'āmma, istiṣlāḥ)

The rational regime whose primary end is this-worldly special interest of the Rulers 
The shar' ' $a$ regime (caliphate, imamate) whose end is this-worldly and other-worldly universal common good (al-Mașālih alKāffa)

Contemporary Muslim politics and Ibn Khaldun's typology

Comparative politics: methods and contents of decision-making

'Political' and 'social' democracy

The Islamic democracy $v s$ 'political' and 'social' democracy decision-making in environmental engineering systems planning

Response of political systems to public interests

Principles of decision-making methods: the $s h \bar{u} r \bar{a}$ (consultation) method of decision-making

Concepts of planning for environmental engineering systems

Discussion

\section{Islamic welfare economics and its implications for environmental} engineering systems planning

Introduction

Islamic economic welfare function: objectives, principles, and criteria

God's ownership of the universe

Universal human brotherhood, equality, and economic trusteeship

Mutual economic aid and co-operation

Methods of acquiring income and wealth

Ownership and enterprise: public vs private sector

Economic egalitarianism: redistribution of income and wealth through social spending

Criteria of social spending: public spending (taxation, and beneficiary charges), and private spending (charity, or philanthropy)

Fiscal planning and sociopolitical decision-making: the role of $\operatorname{shari}^{-6} a$ democracy

Implications of Islamic economic welfare function for fiscal planning of environmental resources development

Allocation of resources

Economic stabilisation

Distribution of income

Implications of Islamic welfare economics for environmental engineering systems planning

Financing and pricing public projects and utilities

7 Imitative-innovative patterns of socio-cultural rejuvenation: Islamic ideological and technological 'modernisations'

Introduction

Basic patterns of culture: the ideal and model, and the actual or behavioural

Cultural relativism: an appreciation of alien cultural patterns

Political modernisation: 'Islamisation' or 'westernisation'?

Basic patterns of socio-cultural rejuvenation through imitation and innovation 
Imitation-innovation processes in rejuvenation of early postQuranic Islamic culture

'Islamicisation' of the West: imitation-innovation processes in Catholic-Protestant reformations and Renaissance

Universal patterns of imitative-innovative rejuvenation of empirical socio-cultural systems

Summary and conclusions: imitative-innovative re juvenation of Islamic

Glossary environmental engineering systems

References

Bibliography 


\section{Acknowledgements}

The author and publishers wish to thank all those who have helped in the preparation and publication of this book. If any sources have not been acknowledged the publishers will be pleased to make the necessary arrangements at the first opportunity. 